\title{
Retensi Nitrogen dan Konversi Pakan Ayam Lokal Persilangan yang Diberi Ekstrak Umbi Dahlia (Dahlia variabilis) sebagai Sumber Inulin
}

\author{
A. F. Fanani, N. Suthama dan B. Sukamto \\ Fakultas Peternakan dan Pertanian, Universitas Diponegoro, \\ Jalan Prof. H. Soedarto, SH, Tembalang 50275 Semarang \\ E-mail: anharfaisalf@yahoo.com
}

\begin{abstract}
ABSTRAK
Penelitian ini bertujuan untuk mengevaluasi pemberian ekstrak umbi bunga dahlia sebagai sumber inulin terhadap retensi nitrogen dan konversi pakan ayam lokal persilangan (ayam kampung jantan dengan ayam niaga petelur betina). Materi yang digunakan adalah ayam lokal persilangan (unsex) sebanyak 160 ekor umur 3 minggu yang diseragamkan bobot badan dengan rata-rata $180,46 \pm 1,21 \mathrm{~g}$ dan diberi perlakuan selama 8 minggu. Rancangan yang digunakan adalah rancangan acak lengkap (RAL) dengan 4 perlakuan dan 4 ulangan (@10 ekor). Perlakuan yang diuji sebagai berikut : T0 (Ransum basal tanpa ekstrak umbi dahlia sebagai kontrol), T1 (Ransum basal + ekstrak umbi dahlia 0,39\%), T2 (Ransum basal + ekstrak umbi dahlia 0,78\%), T3 (Ransum basal + ekstrak umbi dahlia 1,17\%). Parameter penelitian yang diamati adalah retensi nitrogen, nilai energi metabolis dan konversi pakan. Data yang diperoleh diolah dengan ANOVA dan dilanjutkan dengan Uji Duncan taraf 5\%. Pemberian ekstrak umbi dahlia berpengaruh $(\mathrm{P}<0,05)$ terhada pretensi nitrogen dengan nilai T0-T3 (1,3g, 1,47g, 1,43g, 1,7g) dan konversi pakan $(4,15,3,58,3,75,3,47)$, namun tidak berpengaruh pada nilai energi metabolis. Dapat disimpulkan bahwa penggunaan inulin dari ekstrak umbi dahlia level tertinggi T3 $(1,17 \%)$ dapat meningkatkan retensi nitrogen dan memperbaiki konversi pakan ayam lokal persilangan.
\end{abstract}

Kata kunci: umbi dahlia, inulin, retensi nitrogen, konversi pakan, ayam lokal persilangan

\section{Nitrogen Retention and Feed Conversion of Crossbred Local Chicken Fed Dahlia Tuber Extract (Dahlia variabilis) for Inulin Source}

\begin{abstract}
The research was aimed to evaluate used dahlia tubersextract as inulinsource onnitrogen retention and feed conversion of crossbred local chicken (male native chicken $\times$ female laying hen). Three weeks old 160 unsex birds with average body weight $180.46 \pm 1.21 \mathrm{~g}$ were kept until 8 weeks. The experimentwas designed ascompletely randomized design with 4 treatments and 4 replications (@10 birds). Treatments applied were T0: basal ration, T1: ration $+0.39 \%$ extract, T2: ration $+0.78 \%$ extract, T3: ration $+1.17 \%$ extract. Parameters observed werenitrogen retention, energy metabolism and feed conversion. The data were statistically analyzed according to ANOVA and continued by Duncan test at the level of 5\%. The results showed that feeding dahlia tuberextract significantly affect $(P<0.05)$ nitrogen retentionwith value T0-T3 $(1.3 \mathrm{~g}, 1.47 \mathrm{~g}, 1.43 \mathrm{~g}, 1.7 \mathrm{~g})$ and feed conversion $(4.15$, $3.58,3.75,3.47)$, but not significant of energy metabolism. In conclusion, the higher levels of feeding inulin in the form of extract in $T 3(1.17 \%)$, increase nitrogen retention and improve feed conversionof crossbred local chicken.
\end{abstract}

Key words: Dahlia tubers, inulin, nitrogen retention, feed conversion, crossbred local chicken 


\section{PENDAHULUAN}

Pesatnya perkembangan jumlah penduduk disertai meningkatnya kesadaran masyarakat terhadap gizi mengakibatkan permintaan protein hewani termasuk produk asal unggas meningkat. Industri ayam broiler tahun 2010 memberikan kontribusi sebesar 1,45 juta ton $(63,3 \%)$ dari total produksi daging nasional 2,3 juta ton, sementara kontribusi telur ayam niaga petelur mencapai 0,95 juta ton $(70,4 \%)$ dari total produksi telur nasional 1,37 juta ton (Dirjen Peternakan dan Kesehatan Hewan, 2011).Jumlah konsumsi protein hewani meningkat dari 5,51 g/kapita/hari pada tahun 2006 menjadi 6,15 g/kapita/hari pada tahun 2010 (Dirjen Peternakan dan Kesehatan Hewan, 2012). Kondisi ini menjadi peluang bagi pengembangan ayam lokal yang jumlahnya hanya $25 \%$ dari total ayam broiler untuk memenuhi konsumsi protein hewani dalam negeri.

Perkembangan ayam lokal sangat lambat jika dibandingkan ayam broiler, sehingga permintaan masyarakat terhadap produk ayam lokal dalam waktu singkat belum dapat dipenuhi. Perkembangan ayam lokal yang lambat dikarenakan produktivitasnya rendah. Oleh karena itu, perlu dilakukan upaya untuk mempercepat pertumbuhan, sehingga waktu pemotongan lebih pendek. Upaya yang dapat dilakukan dengan mengembangkan ayam lokal persilangan antara betina ayam ras dengan pejantan ayam lokal atau yang sering disebut dengan ayam lokal super.

Keunggulan ayam lokal persilangan yaitu pertumbuhan dan umur pemotongan lebih cepat dari ayam lokal biasa. Peran ayam lokal tidak dapat diabaikan demi memenuhi selera konsumen karena memiliki karakteristik khas terdapat di dalamnya yang secara umum disukai oleh masyarakat (Haryono et al., 2012). Sebagaimana dengan unggas pada umumnya, ayam lokal persilangan bila diupayakan untuk meningkatkan produksi dan reproduksi sangat tergantung pada faktor manajemen dan lingkungan. Faktor manajemen yang dimaksud meliputi manipulasi dan formulasi pakan. Manipulasi pakan dalam upaya untuk meningkatkan produksi, baik telur maupun daging selalu dikaitkan dengan pemberian pakan yang sesui kebutuhan. Pemberian prebiotik merupakan satu bentuk manipulasi pakan yang dapat diterapkan.

Senyawa yang termasuk prebiotik adalah inulin, fructo-oligosacharides (FOS), iso-malto oligoschacarides, lactosuccrose, lactoluse, pyro-dextrine, soy oligosacharides, trans-oligoscharides dan xylo-oligoscharides (Azhar, 2009). Umbi bunga dahlia (Dahlia variabilis) merupakan satu sumber inulin sebagai prebiotik yang sangat potensial. Bunga dahlia banyak dibudidayakan di Indonesia, selain bunganya yang indah, umbinya juga dapat dimanfaatkan sebagai sumber inulin. Kadar inulin pada umbi tanaman dahlia yaitu $65,7 \%$ berat kering (Rukmana, 2004). Prebiotik inulin merupakan substrat karbohidrat yang tidak dicerna bagi inang, tetapi dapat dimanfaatkan oleh mikroba usus (Scholz-Ahrens et al., 2001).

\section{Menurut Bezkorovainy (2001)} penggunaanprebiotik menjadi pendekatan untuk meningkatkan peran bakteri endogen yang menguntungkan dalam saluran pencernaan. Kondisi ini berdampak pada perbaikan kondisi saluran pencernaan akibat perubahan komposisi bakteri endogen, sehingga diharapkan penggunaan prebiotik inulin mampu meningkatkan retensi nitrogen pada ayam lokal persilangan yang ditandai dengan peningkatan produktivitas. Oleh karena itu, perlu dilakukan penelitian mengenai pemberian inulin berasal dari umbi bunga dahlia terhadap peningkatan produktivitas ayam lokal persilangan berdasarkan parameter retensi nitrogen, nilai energi metabolis dan konversi pakan.

\section{MATERI DAN METODE}

Ayam lokal persilangan (ayam local jantan dengan ayam niaga petelur betina) umur 3 minggu sebanyak 160 ekor unsex dengan bobot badan rata-rata 180,46 $\pm 1,21$ $\mathrm{g}$ dipelihara selama 8 minggu dalam 
Tabel 1. Bahan pakan dan kandungan nutrien periode starter dan finisher

\begin{tabular}{lcc}
\hline Bahan Pakan & Starter & Finisher \\
\hline Jagung kuning & 51,30 & 47,00 \\
Bekatul & 15,00 & 25,00 \\
Bungkilkedelai & 22,50 & 18,00 \\
Tepungikan & 10,00 & 8,00 \\
$\mathrm{CaCO}_{3}$ & 0,70 & 1,20 \\
Vitamin dan mineral & 0,50 & 0,80 \\
Total & 100,00 & 100,00 \\
Kandungannutrien : & & \\
Energimetabolis (kkal/kg)* & $2.821,89$ & $2.872,80$ \\
Protein kasar $(\%)^{* *}$ & 19,46 & 17,56 \\
Lemakkasar (\%)** & 4,99 & 5,75 \\
Seratkasar $(\%)^{* *}$ & 4,81 & 5,94 \\
Metionin $(\%)^{* * *}$ & 0,44 & 0,39 \\
Lisin $(\%)^{* * *}$ & 1,26 & 1,08 \\
Arginin $(\%)^{* * *}$ & 1,39 & 1,23 \\
Kalsium $(\%)^{* *}$ & 1,02 & 1,01 \\
Fosfor $(\%)^{* *}$ & 0,66 & 0,64 \\
\hline Kerangan : & & \\
\hline
\end{tabular}

\section{Keterangan :}

* EM $(\mathrm{kkal} / \mathrm{kg})$ berdasarkan rumus Balton $=40,81[0,87(\mathrm{PK}+2,25 \mathrm{x} \mathrm{LK}+\mathrm{BETN})+\mathrm{k}]$

** Di-analisis di Laboratorium Ilmu Nutrisi dan Pakan Fakultas Peternakan dan Pertanian Universitas Diponegoro (2013).

*** Berdasarkan tabel kandungan nutrient bahan pakan (NRC, 1994).

kandang individu dengan ukuran $30 \times 20 \times 25$ $\mathrm{cm}$. Pemeliharaan dilakukan di Kandang Digesti Fakultas Peternakan dan Pertanian Universitas Diponegoro. Penelitian dilakukan secara eksperimental berdasarkan rancangan acak lengkap (RAL) dengan 4 perlakuan dan 4 ulangan (@ 10 ekor). Proses ekstraksi umbi bunga dahlia berdasarkan modifikasi metode Azhar (2009) and Ma'aruf et al. (2011). Kadar prebiotik inulin dari ekstrak umbi bunga dahlia sebesar $88,95 \%$ (diuji dengan metode HPLC).

Perlakuan penelitian sebagai berikut: $\mathrm{T} 0=$ Ransum basal

$\mathrm{T} 1$ = Ransum basal + ekstrak umbi dahlia $0,39 \%$ (setara dengan $0,34 \%$ inulin)

$\mathrm{T} 2=$ Ransum basal + ekstrakumbi dahlia $0,78 \%$ (setara dengan $0,69 \%$ inulin)

$\mathrm{T} 3$ = Ransum basal + ekstrakumbi dahlia $1,17 \%$. (setara dengan $1,04 \%$ inulin)

Ransum yang digunakan terdiri dari ransum starter yang diberikan sampai umur 45 hari dan finisher diberikan pada umur 46 sampai 77 hari. Bahan penyusun ransum terdiri dari jagung giling, dedak padi halus, tepung ikan, bungkil kedelai, $\mathrm{CaCO}_{3}$ dan vitamin-mineral non antibiotik. Susunan dan kandungan nutrient ransum penelitian terlihat pada Tabel 1.

Parameter yang diamati adalah retensi nitrogen, nilai energi metabolis dan konversi pakan. Pengambilan parameter retensi nitrogen dan nilai energi metabolis berdasarkan metode koleksi total, yaitu dilakukan koleksi total ekskreta selama 3 hari berturut-turut. Retensi nitrogen dan nilai energi metabolis yang diukur dikoreksi dengan nitrogen dan energi endogenuous. Retensi nitrogen diukur dengan cara menghitung jumlah nitrogen yang dikonsumsi dikurangi nitrogen ekskreta yang dikoreksi nitrogen endogenous.

Retensi Nitrogen $(\mathrm{g})=\mathrm{N}$ konsumsi (N Ekskreta - N Endogenous)

Keterangan:

$\mathrm{N}$ Konsumsi $(\mathrm{g}) \quad=$ hasil kali antara 
jumlah konsumsi dengan \% nitrogen ransum

N ekskreta $(\mathrm{g}) \quad=$ hasil kali antara jumlah ekskreta dengan \% nitrogen ekskreta $\mathrm{N}$ Endogenous $(\mathrm{g}) \quad=$ hasil kali antara jumlah ekskreta dengan \% nitrogen ekskreta endogenous.

Perhitungan energi metabolis kemudian dihitung menurut metode (Sibbald, 1977) sebagai berikut:

$\mathrm{EM}=$

$\{($ TPp x BKp x EBp $)-\{($ TKf x BKf x EBf $)-\{($ TFk x EBk $)\}$ (TPp x BKp)

$\begin{array}{cl}\text { Keterangan : } & \\ \text { EM } & =\text { Energi Metabolis }(\mathrm{kkal} / \mathrm{kg}) \\ \text { TPp } & =\text { Total Pemberian Pakan } \\ \text { BKp } & =\text { Bahan Kering Pakan } \\ \text { EBp } & =\text { Energi Bruto Pakan } \\ \text { TKf } & =\text { Total Kering Feses } \\ \text { BKf } & =\text { Bahan Kering Feses } \\ \text { EBf } & =\text { Energi Bruto Feces } \\ \text { TFk } & =\text { Total Feses Endogenuous } \\ \text { EBk } & =\text { Energi Bruto Feces } \\ & \text { Endogenuous }\end{array}$

Konversi pakan diperoleh dengan cara menghitung jumlah konsumsi pakan (g) dibagi dengan pertambahan bobot badan $(\mathrm{g})$ selama 8 minggu. Data yang diperoleh dianalisis dengan analisis varian (ANOVA) untuk mengetahui pengaruh perlakuan yang dilanjutkan uji Duncan taraf 5\%. Model matematik rancangan acak lengkap (RAL) yang digunakan menurut Steel dan Torrie (1995).

\section{HASIL DAN PEMBAHASAN}

Hasil penelitian penggunaan ekstrak umbi bunga dahlia sebagai sumber prebiotik inulin terhadap retensi nitrogen, nilai energi metabolis,dan konversi pakan dapat dilihat pada Tabel 2 .

Berdasarkan hasil statistik, penggunaan ekstrak umbi bunga dahlia berpengaruh nyata $(\mathrm{P}<0,05)$ terhadap retensi nitrogen. Pemberian ekstrak umbi bunga dahlia mampu meningkatkan retensi nitrogen karena inulin dapat termanfaatkan oleh bakteri asam laktat (BAL) saluran pencernaan usus halus. Apabila retensi nitrogen meningkat, member indikasi bahwa protein yang tercerna semakin banyak. Menurut Guilloteau et al. (2010) pemanfaatan prebiotik oleh BAL menghasilkan short chain fatty acid (SCFA), sehingga menyebabkan kondisi $\mathrm{pH}$ saluran pencernaan menjadi menurun, akibatnya menekan pertumbuhan bakteri patogen. Kondisi pH duodenum menurun dari 6,1 pada perlakuan T0 menjadi 5,45 dengan perlakuan T3 (Krismiyanto, data belum dipublikasikan). Penurunan $\mathrm{pH}$ saluran pencernaan dapat meningkatkan aktivitas proteolisis, akibatnya akan meningkatkan penyerapan protein, sehingga pada penelitian ini berpengaruh terhadap jumlah nitrogen yang diretensikan.

Pengaruh derajat polimerasi (DP) dan kadar tannin pada ekstrak yang rendah turut berpengaruh terhadap pemanfaatan ekstrak umbi bunga dahlia oleh BAL. Menurut Van Loo (2007), bahwa inulin dengan $\mathrm{DP}<10$ cepat difermentasi dan berinteraksi secara selektif oleh bakteri usus. Proses ekstraksi tepung umbi bunga dahlia menyebabkan kandungan prebiotik inulin dengan DP pendek pada ekstrak lebih tinggi karena sifatnya yang mudah larut akibat proses ekstraksi dengan air panas dan menggunakan etanol. Derajat polimerisasi mendefinisikan jumlah rantai fructosyl yang bervariasi pada berbagai sumber dengan kisaran 2 sampai 60 dengan rata-rata 12 pada inulin dari tanaman (Lima et al., 2011). Komposisi BAL dan bakteri patogen dapat memengaruhi fungsi usus dalam hubungannya dengan kesehatan usus, apabila kesehatan usus lebih baik, maka sekresi enzim pencernaan meningkat yang pada akhirnya kecernaan nutrien menjadi lebih efisien yang dilihat pada retensi nitrogen. Kesehatan saluran pencernaan ayam lokal persilangan didukung data BAL duodenum meningkat dari $1,18 \times 10^{3} \mathrm{cfu} / \mathrm{g}$ pada T0 menjadi $2,5 \times 10^{4} \mathrm{cfu} / \mathrm{g}$ dengan perlakuan T3 (Krismiyanto, data belum dipublikasikan). Menurut Mountzouris et al. 
Tabel 2. Rataan retensi nitrogen, nilai energi metabolis (EM) dan konversi pakan pada masing-masing perlakuan

\begin{tabular}{lcccc}
\hline Parameter & T0 & T1 & T2 & T3 \\
\hline Retensi nitrogen $(\mathrm{g})$ & $1,23 \pm 0,14^{\mathrm{c}}$ & $1,47 \pm 0,07^{\mathrm{b}}$ & $1,43 \pm 0,11^{\mathrm{b}}$ & $1,7 \pm 0,06^{\mathrm{a}}$ \\
Nilai EM (kkal/kg) & $2227,29 \pm 128,43$ & $2238,75 \pm 66,98$ & $2306,36 \pm 177,81$ & $2341,15 \pm 78,75$ \\
Konversi pakan & $4,15 \pm 0,26^{\mathrm{a}}$ & $3,58 \pm 0,16^{\mathrm{b}}$ & $3,75 \pm 0,16^{\mathrm{b}}$ & $3,47 \pm 0,22^{\mathrm{b}}$ \\
\hline
\end{tabular}

Keterangan : ${ }^{\text {abc }}$ Menunjukan ada perbedaan nyata $(\mathrm{P}<0,05)$

(2010) pemberian perlakuan dengan prebiotik dapat memperbaiki komposisi mikroba di dalam saluran pencernaan, memperbaiki fungsi dan kesehatan usus yang berefek meningkatkan penyerapan nutrisi tanpa mengakibatkan adanya residup ada ternak. Ghiyasi et al. (2007) melaporkan dengan menggunakan prebiotik pada ransum ayam broiler dapat meningkatkan kecernaan dan penyerapan nutrien.

Energi metabolis merupakan hasil pengurangan konsumsi energi bruto dengan ekskresi energi bruto melalui ekskreta. Penggunaan ekstrak umbi bunga dahlia diharapka nmampu menurunkan jumlah ekskresi energi melalui ekskreta sehingga penyerapan energi meningkat. Perbaikan penyerapan pada ayam lokal persilangan diusahakan dengan manipulasi pakan menggunakan ekstrak umbi bunga dahlia seperti disajikan pada Tabel 2 yang ternyata nilai energi metabolistidak berbeda $(\mathrm{P}>0,05)$ antar perlakuan. McDonald et al. (2002) berpendapat bahwa rendahnya daya cerna terhadap suatu bahan pakan mengakibatkan banyaknya energi yang hilang dalam bentuk ekskreta sehingga nilai energi metabolis menjadi rendah. Hasil uji statistik dengan penggunaan ekstrak menunjukkan hasil yang tidak berbeda, namun secara numerik seiring dengan penambahan ekstrak umbi bunga dahlia menunjukkan peningkatan nilai energi metabolis.

Konversi pakan merupakan ukuran ternak dapat memanfaatkan pakan yang diberikan secara efisien dengan bobot badan yang dihasilkan. Analisis ragam konversi pakan diperlihatkan pada Tabel 2. Hasil analisis konversi pakan menunjukkan bahwa terdapat pengaruh yang nyata $(\mathrm{P}<0,05)$. Terlihat dari semakin menurunnya nilai konversi dengan meningkatnya level pemberian ekstrak umbi bunga dahlia sebagai sumber prebiotik inulin. Konversi pakan erat hubungannya dengan efisiensi penggunaan pakan selama pertumbuhan dan didefinisikan sebagai perbandingan antara konsumsi pakan dengan unit pertumbuhan bobot badan (Zainal, 2012).

Besar kecilnya nilai konversi pakan dipengaruhi oleh daya cerna ayam pedaging, kualitas pakan yang dikonsumsi, dan keserasian nilai kandungan zat makanan dalam pakan. Meningkatnya kecernaan protein akan menyebabkan peningkatan retensi protein yang dapat dimanfaatkan tubuh, sehingga akan memengaruhi terhadap pertumbuhan yang ditandai dengan peningkatan bobot badan, yaitu 894,19 g pada T0 menjadi $1.066,5 \mathrm{~g}$ pada T3. Konversi pakan dimaksudkan untuk mengetahui kemampuan ayam dalam mengubah pakan yang dikonsumsi menjadi daging. Resnawati et al. (2000) melaporkan konversi pakan pada persilangan Ayam Kedu×Kampung sebesar 3,94 yang dipelihara pada umur 12 hari.

Semakin besar angka konversi pakan maka penggunaan pakan tersebut kurang ekonomis, sebaliknya jika angka konversi itu semakin kecil berarti semakin ekonomis. Perlakuan T0 nyata paling tinggi nilai konversi pakan dari pada yang mendapat perlakuan dengan ekstrak (T1-T3). Berhubung kurangnya asupan nutrient terutama protein tanpa adanya bantuan prebiotik inulin, disamping karena tidak adanya stimulator BAL. Faktor-faktor yang memengaruhi konversi pakan antara lain konsumsi pakan, berat badan, kandungan dalam ransum, lingkungan pemeliharaan, stress dan jenis kelamin (Lokapirnasari et al., 2012).

Menurut Anggorodi (1980) konversi 
pakan merupakan jumlah pakan yang dikonsumsi persatuan jumlah produk dalam hal ini bobot ternak. Walaupun dalam penelitian ini konsumsi ransum pada T0 nyata paling kecil, namun bobot badan yang dihasilkan juga nyata paling rendah. Hal ini menunjukkan bahwa kurang optimalnya kemampuan ayam dalam mengubah pakan yang dikonsumsi menjadi produk karena tidak ada bantuan prebiotik inulin asal ekstrak umbi bunga dahlia.

\section{SIMPULAN}

Simpulan hasil penelitian bahwa penggunaan inulin dari ekstrak umbi dahlia level tertinggi T3 (1,17\%) dapat meningkatkan retensi nitrogen dan memperbaiki konversi pakan ayam lokal persilangan.

\section{DAFTAR PUSTAKA}

Anggorodi, H R. 1980. Ilmu Makanan Ternak Umum. PT Gramedia Pustaka Utama. Jakarta.

Azhar, M. 2009. Inulin sebagai prebiotik. J. Sainstek. 12 (1): 23-26.

Bezkorovainy, A. 2001. Probiotics: determinants ofsurvival and growth in the gut. Am. J. Clin. Nutr. 73: 399-405.

Direktorat Jenderal Peternakan dan Kesehatan Hewan. 2011. Statistik Peternakan dan Kesehatan Hewan. Kementrian Pertanian RI, Jakarta.

Direktorat Jenderal Peternakan dan Kesehatan Hewan. 2012. Statistik Peternakan dan Kesehatan Hewan. Kementrian Pertanian RI, Jakarta.

Ghiyasi, M., M. Rezaeiand H. Sayyahzadeh, 2007.Effect of prebiotic (fermacto) in low protein diet on performance and carcass characteristics of broiler chicks.Poult.Sci. 6 (9): 661-665.

Guilloteau, P., L. Martin, V. Eeckhaut, R. Ducatelle, R. Zabielski and F. Van Immerseel. 2010. From the gut to the peripheral tissues: the multiple effects of butyrate. J. Nutr. Res. Rev. 23: 366-384.

Haryono, B. Tiesnamurti dan C. Hidayat. 2012. Prospek Usaha Ayam Lokal Mengisi Pangsa Pasar Nasional. Workshop Nasional Unggas Lokal. Balai Penelitian
Ternak, Bogor. Hal. 3-10.

Lima, D.M., P. Fernandes, D.S. Nascimento, R. De Cássia. F. Ribeiro and S.A. de Assis. 2011. Fructose syrup: A biotechnology asset. Food Technol. Biotechnol. 49 (4) 424-434.

Lokapirnasari, I.P., Soewarno dan Y. Dhamayanti. 2012. Potensi crude spirulina terhadap protein effisiensi rasio pada ayam petelur potency of crude spirulina on protein efficiency ratio in laying hen. Veterinaria Medika. 2 (1): 1-4.

Ma'aruf, Y., M. Azhardan dan B. Oktavia. 2011. Penentuankadar RBB pada dye-inulin secara HPLC melalui pembentukan senyawa dye-inulin. Laporan penelitian. Fakultas Matematika dan Ilmu Pengetahuan Alam. Universitas Negeri Padang. Padang.

McDonald, P., R.A. Edwards, J. F. D. Greenhalgh and C. A. Morgan. 2002. Animal Nutrition. 6th Edition. Longmann Singapore Publishers (Pte) Ltd., Singapore.

Mountzouris, K.C., P. Tsitrsikos, I. Palamidi, A. Arvaniti, M. Mohnl, G. Schatzmayr and K. Fegeros. 2010. Effects of probiotic inclusion levels in broiler nutrition on growth performance, nutrient digestibility, plasma immunoglobulins, and cecalmicroflora composition. Poult. Sci. 89 (1):58-67.

National Research Council. 1994. Nutrient requirements of poultry. 9th Revised Edition. Washington, D.C. National Academy Press. USA.

Resnawati, H., A.G. Nataamijaya, Ukakusnado, Helmyhamid, S. Iskandar dan C. Sugiyono. 2000. Optimalisasi teknologi budidaya ternak ayam lokal penghasil daging dan telur. Seminar Nasional Peternakan dan Veteriner. Bogor. pp 172176.

Rukmana, R. 2004. Dahlia Prospek Agribisnis dan Teknik Budi Daya. Kanisius, Yogyakarta.

Scholz-Ahrens, K.E. Schaafsma, G.E.G.H.M. Heuvel and J. Schrezenmeir. 2001. Effect of prebiotics on mineral metabolism. Am. J. Clin. Nutr. 73 (2): 4592-4605.

Sibbald, I.R. 1977. A test of the additivity of true metabolizable energy values of feeding stuff. Poult. Sci. 56: 363-366.

Steel, R.G.D. dan J.H. Torrie. 1995. Prinsip Prosedur Statistik Suatu Pendekatan 
Biometrik Cetakan ke-4. (Diterjemahkan oleh Sumantri, B). PT. Gamedia Pustaka Utama, Jakarta.

Van Loo, J. 2007. How chicory fructans contribute to zootechnical performance and well-being in livestock and companion animals. J. Nutr. 137(11):
2594-2597.

Zainal, H., T. Sartika, D. Zainuddin dan Komarudin. 2012. Persilangan pada Ayam Lokal (KUB, Sentul, Gaok) untuk Meningkatkan Produksi Daging Unggas Nasional. Workshop Nasional Unggas Lokal. Bogor. pp 102-108. 